\title{
Outbreaks in the age of syndemics: New insights for improving Indigenous health
}

\author{
A Andermann ${ }^{1,2,3 *}$
}

\section{Abstract}

Conventional approaches for the prevention and control of communicable diseases within Indigenous contexts may benefit from new insights arising from the growing interest in syndemics. Syndemics is a term used to describe a conceptual framework for understanding diseases or health conditions, and how these are exacerbated by the social, economic, environmental and political milieu in which a population is immersed. The use of conventional approaches for outbreak prevention and control remains the bedrock of intervention in the field of communicable diseases; yet on their own, these strategies are not always successful, especially within contexts of marginalization and disadvantage. A broader approach is needed; one that examines the systemic factors involved, understands how various policies and systems support or hinder effective responses and identifies the structural changes needed to create more supportive environments and increase the resilience of the population. In an Indigenous context, whether the focus is on hepatitis C, tuberculosis, HIV or water-borne diseases, it is important to recognize that a) social determinants contribute to the emergence and persistence of outbreaks, b) conventional approaches to communicable disease control are necessary but not sufficient, and c) using a "syndemics lens" can leverage action at multiple levels to tackle the root causes of poor health and inform more effective strategies for improving Indigenous health and reducing health inequities.

\author{
Affiliations \\ ${ }^{1}$ First Nations and Inuit Health \\ Branch, Health Canada, Montréal, \\ QC \\ ${ }^{2}$ Department of Family Medicine, \\ Department of Epidemiology, \\ Biostatistics and Occupational \\ Health, McGill University, \\ Montréal, QC \\ ${ }^{3}$ Department of Public Health, \\ Cree Board of Health and Social \\ Services of James Bay, Montréal, \\ QC
}

\section{Correspondence: anne.} andermann@mail.mcgill.ca
Suggested citation: Andermann A. Outbreaks in the age of syndemics: New insights for improving Indigenous health. Can Commun Dis Rep. 2017;43(6):125-32. https://doi.org/10.14745/ccdr.v43i06a02

\section{Introduction}

There is a growing consensus in Canada that we need to improve the state of Indigenous health. It is well-known that, on average, Indigenous persons have a shorter life expectancy and shoulder a greater burden of chronic diseases. Communicable diseases also disproportionately affect Indigenous Canadians; for instance, the Indigenous population accounts for about $4.3 \%$ of Canada's total population but $17 \%$ of the tuberculosis burden, and newly-diagnosed infections among the Inuit are 270 times more likely than among Canadian-born non-Indigenous persons (1). Several factors are believed to contribute to this discrepancy, including historical factors, overcrowded living conditions and health system-related challenges. As well, the concurrence of health conditions such as HIV, diabetes and substance use increases the likelihood that latent tuberculosis infection will progress to active disease (2).

Recently, there has been a growing interest in the concept of syndemics within the global public health community. Syndemics is a term used to describe a conceptual framework for understanding diseases or health conditions, and how these are exacerbated by the social, economic, environmental and political milieu in which a population is immersed. This notion describes how co-existing health conditions can negatively reinforce each other and lead to worsening outcomes and greater vulnerability within the context of marginalization and disadvantage (3). Rethinking current strategies for communicable disease prevention and control in an Indigenous context would certainly benefit from a "syndemics lens" to guide responses that go beyond conventional approaches (i.e., vaccination and contact tracing), to include policies and programs that address the underlying and often structural root causes.

The concept of syndemics is closely linked to health equity and social determinants of health (4). The World Health Organization defines social determinants as "the conditions in which people are born, grow, work, live, and age, and the wider set of forces and systems shaping the conditions of daily life" (5), such as economic policies, social norms and political systems. Those living in conditions of disadvantage are often more exposed to and less able to protect themselves from external threats to health and therefore suffer worse health outcomes. For example, a multi-cohort study and meta-analysis published recently in The Lancet followed over 1.7 million patients for an average of 13 years and found that participants aged $40-85$ years with a lower socio-economic status had approximately $40 \%$ higher premature mortality and died on average two years earlier than those with a higher socio-economic status (6).

Social determinants of health include wide-ranging factors such as income, social support, early childhood development, education, employment, housing and gender (7). In an Indigenous context, extending beyond these social explanatory factors, there are even more deeply-embedded factors such as the history of colonization, jurisdictional ambiguity, structural 
racism, intergenerational trauma and even the right to land ownership and enfranchisement, all of which can exert an important influence on population health, often in insidious ways (8). Indeed, there exist many frameworks that attempt to explain what social determinants are, how these factors interact and impact health, as well as ways to take action to reduce health inequities (9). In relation to Indigenous health, one of the most commonly used frameworks is the First Nations Holistic Policy and Planning Model developed by the Assembly of First Nations (10). This model highlights the importance of self-government and cultural continuity described by Chandler and Lalonde as underpinning determinants of resilience and well-being (11). A strong community is at the core of good health, and relationships (within communities, between communities and with formal institutions) are emphasized as key to building social capital (12). In this model, the holistic influence of the Medicine Wheel is prominent (i.e., focus on physical, mental, emotional and spiritual health), as well as the consideration of health across the entire lifespan (i.e., children, youth, adults and Elders).

While intuitively one might recognize that broader factors are at play, concretely there is the question of how can this new syndemics lens translate into a reduction in communicable disease morbidity and mortality? The purpose of this article is to explore how applying a syndemics lens can be useful in advancing infectious disease prevention and control among Indigenous populations in Canada.

\section{Analysis}

The case for the usefulness of a syndemics lens in strengthening infectious disease prevention and control in Indigenous contexts rests on three basic assertions: Social determinants of health are important contributors to the emergence and persistence of outbreaks; a number of infectious disease threats will not be optimally controlled unless social determinants of health are addressed; and using a syndemics lens can help inform novel approaches in clinical care, population health and public policy that can promote Indigenous health and reduce inequities.

\section{Social determinants contribute to outbreaks}

It is increasingly recognized that "poverty, overcrowding, population displacement, weak health systems, inadequate access to safe water and sanitation and the health status of specific populations are all contributing factors to epidemics and emerging disease outbreaks" (13). Those who live in degraded physical and social environments are at greater risk of contracting, propagating and even dying from communicable diseases (14).

This also holds true for Indigenous populations where it has been shown that "living in a house in need of major repairs, having less than high school education, being unemployed... experiencing food insecurity in the previous 12 months... and having no one to turn to for support in a time of need" are associated with negative health outcomes (15). It is well-documented that the living conditions of many Indigenous Canadians are considerably more precarious than their non-Indigenous counterparts. In 2011, "28\% of on-reserve First Nations people and $30 \%$ of Inuit in Canada lived in crowded homes" as compared with $4 \%$ of non-Indigenous Canadians (16).
Similarly, among Indigenous adults aged 25 to 64 years, "28.9\% had no certificate, diploma or degree" while the proportion for non-Indigenous adults was $12.1 \%$ (17). Off-reserve, "approximately one in five (20.9\%) [Indigenous] households was food insecure, including $8.4 \%$ with severe food insecurity", which is three times higher than non-Indigenous households where $7.2 \%$ were food insecure, including $2.5 \%$ with severe food insecurity (18).

There is a clear correlation between these living conditions and the higher rates of communicable diseases such as tuberculosis, community-acquired methicillin-resistant Staphylococcus aureus (MRSA) and sexually transmitted and blood-borne infections (STBBI) among Indigenous Canadians as compared with non-Indigenous Canadians (19). Indeed, there is a large body of literature linking higher rates of HIV among Indigenous populations to factors such as violence, stigma and discrimination, coupled with mistrust of the health system, "which contributes to poor HIV and health outcomes among Indigenous peoples" (19). An example of this is the recent outbreak of HIV among Indigenous peoples in Saskatchewan, with incidence rates 11 times the national average (20). Developing effective responses and models of care requires multi-faceted approaches to address the various aspects involved (21); such as considering the context of traumatic life experiences (22), including sexual abuse (23), as well as managing comorbidities including other sexually-transmitted infections such as chlamydia, which is "estimated to be almost seven times higher among First Nations adults than the rate of the overall population" (24). It is possible to create culturally adapted approaches to address HIV outbreaks in Indigenous populations whereby $90 \%$ of people living with HIV know their status, are treated and achieve viral suppression. According to one Chief "Communication and confidentiality are key" (25).

Yet a recent report entitled First Peoples, Second Class Treatment describes the structural barriers that many Indigenous peoples continue to struggle with on a daily basis in obtaining access to quality care (26). Other structural barriers exist for a range of basic needs such as access to food, quality housing and clean water. The chronic challenge in accessing clean water on reserves, and the media attention this has received (27), led some people to use alternate unsafe water sources, resulting in water-borne illnesses (28). This complex situation of multiple co-existing epidemics represents a true syndemic, where the "compounding effects of multiple points of social disadvantage yield increasingly negative life outcomes" (15). In addition to vertical programs (i.e., single-disease approaches to communicable disease prevention and control), addressing the interconnected web of health and social challenges would benefit from greater emphasis on "person-centred" and systems-based approaches.

\section{Conventional approaches are necessary but not sufficient}

There is no question that conventional approaches to outbreak response (e.g., contact tracing and treating infectious cases) and promotion of preventive practices (e.g., hand hygiene, vaccination and safer sexual practices) are still the bedrock of communicable disease prevention and control measures (29). Yet, to make an impact on reducing disease incidence and 
mortality, additional tools are needed to better understand and act, not only on health system factors, but also on the wider social, economic and political systems in place (30). It has long been recognized that "working and networking diligently with colleagues and appropriately communicating ideas and information across jurisdictional lines and between scientific disciplines are key to the success" of outbreak prevention and response (29).

With the rise in international travel and the interconnectedness of our global society, broader approaches that consider geopolitical concerns and shifting policy agendas are increasingly important for ensuring national and global health security (31). It has been argued that, in spite of the 2005 revision of the International Health Regulations, preventing public health emergencies of international concern (such as Ebola and Zika) will require stronger investment in health systems, particularly in low- and middle-income countries (32). The rise of antimicrobial resistance has become a United Nations (UN) priority in recent months, emphasizing the need for a unified and global approach to reducing communicable disease threats to health (33). Increasingly, it is clear that prevention cannot simply be transferred to the individual, with messages such as "wash your hands", "wear condoms" and "don't share needles", since individual behavioural change is only one piece of a much larger puzzle.

Indeed, missed opportunities for prevention and inequitable access to care have been identified as major factors in explaining health system inefficiencies (34), and ultimately poorer health outcomes. Health care system leaders are increasingly recognizing the need for a social determinants and population health approach not only for improving health, but also in balancing budgets, by "reducing healthcare demand and contributing to health system sustainability" (35). The health sector can play an important leadership role in addressing health inequities by making action on social determinants a health sector priority, and by integrating disparities reduction into policies, health programs and services (36).

In the realm of Indigenous health, the calls to action of the Truth and Reconciliation Commission (TRC) can serve as an important starting point and driver for making this happen (37). The TRC proposes to "fully adopt and implement the United Nations Declaration on the Rights of Indigenous Peoples as the framework for reconciliation," which states that "Indigenous peoples are equal to all other peoples... while recognizing the right of all peoples to be different, to consider themselves different, and to be respected as such" (38). Both the TRC calls to action and the UN declaration highlight the need to promote greater Indigenous self-determination, child welfare, economic development, justice, culture, language and education, which are all important social determinants of health. In particular, the TRC calls for action to "identify and close the gaps in health outcomes between Aboriginal and non-Aboriginal communities... including infant mortality, maternal health, suicide, mental health, addictions, life expectancy, birth rates, infant and child health issues, chronic diseases, illness and injury incidence, and the availability of appropriate health services." Since the role of the health sector is to improve health (not only to create health services) (39), action on social determinants falls squarely within this mandate. Moreover, the tools to achieve these goals are within reach when one adopts a syndemics lens.

\section{A syndemics-informed approach can address the root causes}

Effective strategies for addressing the social determinants of health have been developed in recent decades for frontline health workers in busy clinical settings (40), for public health professionals working at a population level (41) and even for decision-makers at a public policy level (42). The following analysis explores how some of these best practices can be applied to addressing syndemics, with the aim of improving overall health and reducing inequities among Indigenous populations.

\section{Clinical best practices to address syndemics among Indigenous peoples}

There are now well-articulated best practices for taking action on the social determinants of health in clinical practice; at a patient care level, at a practice level and at a community level (Table 1). These can be applied as useful complements to conventional strategies for preventing and managing communicable diseases in Indigenous populations.

\section{Table 1: A dozen best practices to address syndemics in clinical practice ${ }^{1}$}

\begin{tabular}{|c|c|}
\hline Approach & Best practices \\
\hline $\begin{array}{l}\text { At the patient care } \\
\text { level }\end{array}$ & $\begin{array}{l}\text { Treat patients with dignity and respect and } \\
\text { create a safe space for disclosure } \\
\text { Ask patients about social challenges in a } \\
\text { sensitive and caring way } \\
\text { Allocate a little extra time to address complex } \\
\text { health and social needs } \\
\text { Know about local referral resources } \\
\text { Refer patients and help them access benefits } \\
\text { and support services }\end{array}$ \\
\hline $\begin{array}{l}\text { At the clinic or } \\
\text { nursing station level }\end{array}$ & $\begin{array}{l}\text { Consider adding chart reminders or recall } \\
\text { systems to flag patients at risk } \\
\text { Consider participatory approaches that } \\
\text { engage other clinicians in your practice to } \\
\text { create a culture of reflection and a more } \\
\text { "upstream approach" } \\
\text { Consider alternative models of care such as } \\
\text { outreach, or using patient navigators to assist } \\
\text { patients on their journey through the health } \\
\text { and social systems }\end{array}$ \\
\hline $\begin{array}{l}\text { At the community } \\
\text { level }\end{array}$ & $\begin{array}{l}\text { Reach out to local leaders to discuss the } \\
\text { health and social challenges that are common } \\
\text { in the community } \\
\text { Use clinical experience and research evidence } \\
\text { to advocate for social change } \\
\text { Get involved in community needs assessment } \\
\text { and health planning } \\
\text { Partner with community groups, public health } \\
\text { and local leaders to advance collaborative } \\
\text { initiatives that help address or attenuate the } \\
\text { effects of health inequities }\end{array}$ \\
\hline
\end{tabular}


For example, a nurse working in a remote Indigenous community may become aware that sexually-transmitted infections are very common in the local population, particularly among youth. She notes that few youth spontaneously come to the nursing station unless they have had an acute injury or other emergency requiring immediate care. The nurse, therefore, tries a different approach to develop a relationship of trust with the young people in the community by organizing a weekly "coffee house" and movie night. These become very popular and gradually young people open up about their concerns and the nurse is able to advise them on issues such as healthy relationships, family planning, alcohol and drug use and violence prevention. Over time, more young people visit the clinic to receive sexual health counselling and screening for infectious diseases, as well as treatment and referral for various health and social services. Once the nurse has a deeper understanding of the key challenges and dynamics in the local context, she starts to think about what could be done at the community level to create more supportive environments for health, and initiates a dialogue with the Youth Council leader, the school principal, Elders, natural helpers and other community members, and this leads to a Youth Health gathering to discuss the way forward for creating wider community-level change. Though there are no "one size fits all" solutions, health workers at the frontlines can be important catalysts for taking action on the social determinants of health at multiple levels.

\section{Public health and policy approaches to syndemics in Indigenous populations}

In addition to implementing the action areas of the Ottawa Charter for Health Promotion (43), building healthy public policies and creating supportive environments for health, more recent efforts to reduce health inequities have focused primarily on intersectoral action and a "health in all policies" (HiAP) approach. Intersectoral action involves the collaboration of multiple sectors, such as education, justice and employment in addressing complex challenges. The HiAP approach refers to the involvement and support of all levels of government with strong leadership at the highest levels (44). Increasingly, there are examples of best practices, even within a communicable disease context, on how to create structural change through establishing policy goals, building capacity, fostering multi-level partnerships across sectors and holding leadership accountable for real change (45).

A key element in intersectoral work and the HiAP approach is the engagement and meaningful involvement of those who will most be affected by the decisions being made. Whether at a population or a political level, ethical choices not only involve ensuring that the overall benefits outweigh the harms, and that the distribution of benefits and harms are fair (46), but that there is a fair and transparent process for making such decisions (47). The engagement of Indigenous peoples in decisions that affect their health requires an ongoing process to "create opportunities for community voice and action to affect social and structural conditions that are known to have wide-ranging health effects on communities" (48). In every aspect of decision-making that impacts people's daily lives, Indigenous peoples should be involved in the decision-making process. According to the UN Declaration on the Rights of Indigenous Peoples: "Indigenous peoples have the right to participate in decision-making in matters which would affect their rights, through representatives chosen by themselves in accordance with their own procedures, as well as to maintain and develop their own Indigenous decision-making institutions" (38). There is a saying, that even with the best intentions, there should be "Nothing about us without us." It is the involvement, empowerment and self-determination in shaping and defining solutions to complex problems that are in themselves important outcomes (i.e. a fair and transparent process is part of the solution).

Compared to the clinical arena, decisions made at the population and public policy levels are more complex and include a much larger number of players (49). Particularly when dealing with areas of shared jurisdiction (which is very common when addressing issues relating to Indigenous health) (50), it is important to have the many different partners working together towards a shared goal of better health and reduced inequities. There are limited examples in the published literature of such intersectoral action as it relates to improving the health of Indigenous Canadians (51), but it is starting, and needs to become part of the modus operandi before progress can be made in reducing inequities in Indigenous health.

In addition to formalized tri-partite structures (involving federal, provincial and Indigenous government representation; such as the BC First Nations Health Authority and the Manitoba Inter-Governmental Committee on First Nations Health) (52), which are increasingly being used, there are many ways to develop intersectoral and multi-institution partnerships to overcome areas of jurisdictional ambiguity. For instance, preventing water-borne communicable diseases on reserves is an important challenge, which requires the collaboration of many different individuals and organizations. Legislation governing access to clean water is not without its shortcomings (53). The Walkerton crisis has taught us that even in non-Indigenous settings, breakdowns in water-monitoring and communication can lead to outbreaks of water-borne illness and even deaths, all of which are potentially avoidable. The Walkerton inquiry highlighted the importance of routine testing of water, logging of results and rapid communication of abnormal results with public health officials to ensure appropriate preventive action (e.g., drinking water advisories and ensuring adequate water treatment systems) (54). This is part of a multi-barrier approach to protecting citizens from harm, which is also relevant to Indigenous settings (55).

When developing mechanisms to protect Indigenous peoples from water-borne illness, it is important to have Indigenous and other partners at the same table (or on the same teleconference call) to sort out the details of how to make it work "on the ground." Convening the Regional Medical Officer and the Regional Manager of the Environmental Health Program of the First Nations Inuit Health Branch at Health Canada, the Director of Infrastructure and Housing at the Regional Office of Indigenous and Northern Affairs Canada, the team at the provincial Ministry of Environment responsible for enforcement of provincial water regulations, the person working under the Chief Medical Officer of Health at the provincial Ministry of Health with delegated responsibility for Environmental Health Protection and, of course, representatives from Indigenous communities and/or Indigenous governance organizations-all of whom can then work together, as a necessary first step to develop a shared understanding of the complexities involved 
and to propose strategies to facilitate communication and transparency in achieving shared goals.

This collaborative approach to working through these complexities can help ensure that there is no appearance of a "double standard" when it comes to how water quality is managed on- and off-reserve. If certain municipalities are granted exemptions (e.g., not required to ship the requisite number of water samples each month to the accredited laboratories due to remote location and transportation challenges), then there can be similar allowances for Indigenous communities with the same distance barriers; but the regulations should be applied in a similar manner, regardless of ethnicity and cultural background of inhabitants. If water processing plants need to meet certain accreditation standards or community-based water-monitors must possess specific training certifications recognized by regulation authorities, then these are all specific objectives that should be worked towards to ensure that all peoples are equally protected under the law. In this way, it will be possible to overcome the many structural and organizational barriers to population and policy-level change, including "limited time or resources, inflexible policies, insufficient managerial support and departmental silos" (56). It may not be a quick fix, but moving forward together is likely to identify more effective and sustainable solutions to complex challenges and certainly a more inclusive and fair process. Indeed, there are examples from other jurisdictions of how Indigenous voices have been used in decision-making processes, and these examples can be used as further inspiration (57).

With climate change ushering in a northward progression of communicable disease vectors, such as ticks carrying Lyme disease to Canada, traditional ways of knowing and the wisdom of Elders can be very helpful. There is an Indigenous saying: "We do not inherit the earth from our parents, but borrow it from our children." (58) This points to the wisdom of decision-making that considers the impact on future generations. We have a great deal to learn from Indigenous approaches to health and well-being, not only for our own health, but also for the health of animals, the land and fulfilling our custodial responsibility towards the well-being of our planet $(59,60)$.

\section{Conclusion}

Conventional approaches to communicable disease prevention and control are no longer sufficient in addressing some of the serious infectious disease threats, both in Canada and around the world. While there is increasing interest within the medical and public health communities regarding the importance of a social determinants approach, the conversation on health inequity in Canada has only recently gained traction. We still have a lot to learn about how to assess these inequities and how to better work together, across departments and sectors, to find effective solutions for health and social challenges.

The Truth and Reconciliation Commission highlights the need for greater involvement of Indigenous peoples in creating their own systems, structures and futures. Using a syndemics lens and taking a social determinants approach can help to better appreciate and act on the root causes of poor health as a means of reducing susceptibility and increasing the resilience of all
Canadians, including Canada's Indigenous peoples. As this is an emerging area of action, we need to report on and share best practices and success stories - whether at the clinical, population health or public policy levels - to advance our work together towards creating a healthier, more equitable and sustainable society.

\section{Authors' statement}

The views of this article are those of the author and do not necessarily reflect the views of the Government of Canada.

\section{Conflict of interest}

None.

\section{Acknowledgements}

I would like to thank the Quebec Regional Executive Director of Health Canada's First Nations and Inuit Health Branch, Richard Budgell, for his unassuming leadership in implementing the calls to action of the Truth and Reconciliation Commission and increasing cultural safety and awareness within his circle of influence, as well as Dr. Patricia Huston and my colleagues for their helpful suggestions on drafts of this article.

\section{Funding}

My program of research relating to action on the social determinants within clinical settings (www.mcgill.ca/clear) is supported by Grand Challenges Canada (GCC), Canadian Institutes for Health Research (CIHR), Fonds de la Recherche du Québec-Santé (FRSQ), Fédération des Médecins Spécialistes du Québec (FMSQ) and St Mary's Research Centre, Montréal, Canada.

\section{References}

1. Gallant V, Duvvuri V, McGuire M. Tuberculosis in CanadaSummary 2015. Can Commun Dis Rep. 2017;43(3):77-82. Available from: http://www.phac-aspc.gc.ca/publicat/ ccdr-rmtc/17vol43/dr-rm43-3-4/ar-04-eng.php.

2. Public Health Agency of Canada. Canadian Tuberculosis Standards, 6th Edition. Ottawa; 2007.

3. Hart L, Horton R. Syndemics: committing to a healthier future. Lancet. 2017;389(10072):888-9. DOI: http://dx.doi. org/10.1016/S0140-6736(17)30599-8 PubMed (https://www. ncbi.nlm.nih.gov/entrez/query.fcgi?cmd=Retrieve \&db=PubM ed\&list_uids=28271826\&dopt=Abstract).

4. World Health Organization. Closing the Gap in a Generation: Health Equity through Action on the Social Determinants of Health. Geneva; 2008. Available from: http://apps.who.int/ iris/bitstream/10665/43943/1/9789241563703_eng.pdf. 
5. World Health Organization. Social Determinants of Health. Geneva; 2008. Available from: http://www.who.int/social_ determinants/en/ (accessed May 15, 2016).

6. Stringhini $S$, Carmeli $C$, Jokela M, Avendaño M, Muennig P, Guida F, Ricceri F, d'Errico A, Barros H, Bochud M, Chadeau-Hyam M, Clavel-Chapelon F, Costa G, Delpierre C, Fraga S, Goldberg M, Giles GG, Krugh V, Kelly-Irving M, Layte R, Lasserre AM, Marmot MG, Preisig M, Shipley MJ, Vollenweider P, Zins M, Kawachi I, Steptoe A Mackenbach JP, Vineis P, Kivimaki M, . LIFEPATH consortium. Socioeconomic status and the $25 \times 25$ risk factors as determinants of premature mortality: a multicohort study and meta-analysis of 1.7 million men and women. Lancet. 2017;389(10075):1229-37. DOI: http://dx.doi.org/10.1016/ S0140-6736(16)32380-7. PubMed (https://www.ncbi.nlm. nih.gov/entrez/query.fcgi?cmd=Retrieve\&db=PubMed\&li st_uids=28159391\&dopt=Abstract).

7. The Social Determinants of Health: The Solid Facts. 2nd edition. Marmot M, Wilkinson R, eds. Copenhagen: WHO Regional Office for Europe, 2003. Available from: http:// www.euro.who.int/_data/assets/pdf_file/0005/98438/ e81384.pdf (accessed May 15, 2016).

8. Greenwood M, de Leeuw S, Lindsay N, Reading C. Determinants of Indigenous Peoples' Health in Canada; Beyond the Social. Toronto: Canadian Scholars Press, 2017.

9. Canadian Council on Social Determinants of Health. A Review of Frameworks on the Determinants of Health. Ottawa; 2015. Available from: http://ccsdh.ca/images/ uploads/Frameworks_Report_English.pdf.

10. Assembly of First Nations. First Nations Holistic Policy and Planning a Transitional Discussion Document on the Social Determinants of Health. Ottawa; 2013. Available from: http:// health.afn.ca/uploads/files/sdoh_afn.pdf.

11. Chandler M, Lalonde C. Cultural continuity as a hedge against suicide in Canada's First Nations. Transcult Psychiatry. 1998;35(2):191-219. DOI: http://dx.doi. org/10.1177/136346159803500202.

12. Mignone J, O’Neil J. Social capital as a health determinant in First Nations: an exploratory study in three communities. J Aborig Health. 2005;2(1):26-33.

13. Schiavo R, May Leung M, Brown M. Communicating risk and promoting disease mitigation measures in epidemics and emerging disease settings. Pathog Glob Health. 2014;108(2):76-94. DOI: http://dx.doi.org/10.1179/204 7773214Y.0000000127. PubMed (https://www.ncbi.nlm. nih.gov/entrez/query.fcgi?cmd=Retrieve\&db=PubMed\&li st_uids=24649867\&dopt=Abstract).

14. Sanders D, Sengupta A, Scott V. Ebola epidemic exposes the pathology of the global economic and political system. Int J Health Serv. 2015;45(4):643-56. DOI: http://dx.doi. org/10.1177/0020731415606554. PubMed (https://www. ncbi.nlm.nih.gov/entrez/query.fcgi?cmd=Retrieve\&db=PubM ed\&list_uids=26391140\&dopt=Abstract).

15. Rotenburg C. Social determinants of health for the offreserve First Nations population, 15 years of age and older, 2012. Ottawa; Statistics Canada, 2016. Available from: http:// www.statcan.gc.ca/pub/89-653-x/89-653-x2016010-eng.htm.
16. Kelly-Scott K, Smith K. Aboriginal Peoples: Fact Sheet for Canada. Ottawa: Statistics Canada, 2015. Available from: http://www.statcan.gc.ca/pub/89-656-x/89-656-x2015001eng.pdf (accessed May 15, 2017).

17. Statistics Canada. The educational attainment of Aboriginal peoples in Canada: National Household Survey (NHS), 2011. Ottawa; 2013. Available from: http://www12.statcan.gc.ca/ nhs-enm/2011/as-sa/99-012-x/99-012-x2011003_3-eng.pdf.

18. Health Canada. Household Food Insecurity in Canada in 2007-2008: Key Statistics and Graphics. Ottawa; 2012. Available from: http://www.hc-sc.gc.ca/fn-an/surveill/ nutrition/commun/insecurit/key-stats-cles-2007-2008-eng. php.

19. Negin J, Aspin C, Gadsden T, Reading C. HIV among Indigenous peoples: A review of the literature on HIV-related behaviour since the beginning of the epidemic. AIDS Behav. 2015 Sep;19(9):1720-34. DOI: http://dx.doi.org/10.1007/ s10461-015-1023-0. PubMed (https://www.ncbi.nlm.nih. gov/entrez/query.fcgi?cmd=Retrieve\&db=PubMed\&lis t_uids=25731659\&dopt=Abstract).

20. Leo G. HIV rates on Sask. reserves higher than some African nations: Saskatchewan on-reserve HIV epidemic 'a real Canadian crisis,' says expert. CBC News; June 3, 2015. Available from: http://www.cbc.ca/news/ canada/saskatchewan/hiv-rates-on-sask-reserves-highe r-than-some-african-nations-1.3097231.

21. Vogel L. HIV in Saskatchewan merits urgent response. CMAJ. 2015;187(11):793-4. DOI: http://dx.doi.org/10.1503/ cmaj.109-5105. PubMed (https://www.ncbi.nlm.nih. gov/entrez/query.fcgi?cmd=Retrieve\& $\mathrm{db}=$ PubMed\&lis t_uids=26124233\&dopt=Abstract).

22. Kirmayer LJ, Gone JP, Moses J. Rethinking historical trauma. Transcult Psychiatry. 2014;51(3):299-319. DOI: http://dx.doi. org/10.1177/1363461514536358. PubMed (https://www. ncbi.nlm.nih.gov/pubmed/24855142?dopt=Abstract).

23. Cedar Project Partnership, Pearce M, Christian W, Patterson K, Norris K, Moniruzzaman A, Craib KJP, Schechter MT, Spittal PM. The Cedar Project: historical trauma, sexual abuse and HIV risk among young Aboriginal people who use injection and non-injection drugs in two Canadian cities. Social Science \& Medicine. 2008;66(11):2185-94.

24. Public Health Agency of Canada. Infectious Disease-The Never-ending Threat in: The Chief Public Health Officer's Report on the State of Public Health in Canada, 2013. Ottawa; 2013. Available from: http://www.phac-aspc.gc.ca/ cphorsphc-respcacsp/2013/sti-its-eng.php.

25. Craig M, Piller M. First Nations forum focuses on 'Know Your Status' program success to combat HIV: Global News Toronto, Health. Feb 14, 2017. Available from: http:// globalnews.ca/news/3247047/first-nations-forum-focuse s-on-know-your-status-program-success-to-combat-hiv/.

26. Allan B, Smylie J. First Peoples, Second Class Treatment: The Role of Racism in the Health and Well-being of Indigenous Peoples in Canada. Toronto, ON: Wellesley Institute, 2015.

27. Levasseur J, Marcoux J. Bad water: 'Third World' conditions on First Nations in Canada. CBC News; Oct 14, 2015. Available from: http://www.cbc.ca/news/canada/manitoba/ 
bad-water-third-world-conditions-on-first-nations-in-c anada-1.3269500.

28. Jung J, Skinner K. Foodborne and waterborne illness among Canadian Indigenous populations: a scoping review. Can Commun Dis Rep. 2017;43(1):7-13. Available from: http:// www.phac-aspc.gc.ca/publicat/ccdr-rmtc/17vol43/dr-rm43-1/ ar-02-eng.php.

29. Gregg M. Field Epidemiology. 3rd ed. Oxford: Oxford University Press, 2008.

30. Arauz MJ, Ridde V, Hernández LM, Charris Y, Carabali M, Villar LÁ. Developing a social autopsy tool for dengue mortality: a pilot study. PLoS One [Internet]. 2015;10(2):e0117455. DOI: http://dx.doi.org/10.1371/ journal.pone.0117455. PubMed (https://www.ncbi.nlm. nih.gov/entrez/query.fcgi?cmd=Retrieve\&db=PubMed\&li st_uids=25658485\&dopt=Abstract).

31. Quinn SC, Kumar S. Health inequalities and infectious disease epidemics: a challenge for global health security. Biosecur Bioterror. 2014;12(5):263-73. DOI: http://dx.doi. org/10.1089/bsp.2014.0032. PubMed (https://www.ncbi.nlm. nih.gov/entrez/query.fcgi?cmd=Retrieve\&db=PubMed\&li st_uids=25254915\&dopt=Abstract).

32. Bennett B, Carney T. Public health emergencies of international concern: global, regional, and local responses to risk. Med Law Rev. Epub Mar 31, 2017. PubMed (https:// www.ncbi.nlm.nih.gov/pubmed/28379440?dopt=Abstract).

33. Friedrich MJ. UN Leaders Commit to fight antimicrobial resistance. JAMA. 2016;316(19):1956. PubMed (https://www. ncbi.nlm.nih.gov/pubmed/27838729?dopt=Abstract).

34. Canadian Institute for Health Information. Measuring the Level and Determinants of Health System Efficiency in Canada. Ottawa; 2014. Available from: https://secure.cihi.ca/ free_products/HSE_TechnicalReport_EN_web.pdf (accessed May 15, 2017).

35. Cohen D, Huynh T, Sebold A, Harvey J, Neudorf C, Brown A. The population health approach: A qualitative study of conceptual and operational definitions for leaders in Canadian healthcare. SAGE Open Med [Internet]. 2014;2:1-11. DOI: http://dx.doi. org/10.1177/2050312114522618. PubMed (https://www. ncbi.nlm.nih.gov/entrez/query.fcgi?cmd=Retrieve\&db=PubM ed\&list_uids=26770704\&dopt=Abstract).

36. Government of Canada. Health Disparities Task Group of the Federal/Provincial/Territorial Advisory Committee on Population Health and Health Security. Reducing Health Disparities - Roles of the Health Sector. Ottawa; 2004. Available from: http://www.phac-aspc.gc.ca/ph-sp/ disparities/pdf06/disparities_discussion_paper_e.pdf (accessed May 15, 2017).

37. Truth and Reconciliation Commission. Truth and Reconciliation of Canada: Calls to Action. Winnipeg; 2015. Available from: http://www.trc.ca/websites/trcinstitution/ File/2015/Findings/Calls_to_Action_English2.pdf (accessed May 15, 2017).

38. United Nations. Declaration on the Rights of Indigenous Peoples. New York; 2008. Available from: http://www.un.org/
esa/socdev/unpfii/documents/DRIPS_en.pdf (accessed May $15,2017)$.

39. Asch DA, Volpp KG. What business are we in? The emergence of health as the business of health care. $\mathrm{N}$ Engl J Med. 2012;367(10):888-9. DOI: http://dx.doi.org/10.1056/ NEJMp1206862. PubMed (https://www.ncbi.nlm.nih. gov/entrez/query.fcgi?cmd=Retrieve\&db=PubMed\&lis t_uids=22931228\&dopt=Abstract).

40. Andermann A. Taking action on the social determinants of health in clinical practice; a framework for health professionals. CMAJ [Internet]. 2016;188(17-18):E474-E483. (accessed May 15, 2017). DOI: http://dx.doi.org/10.1503/ cmaj.160177. PubMed (https://www.ncbi.nlm.nih.gov/ entrez/query.fcgi?cmd=Retrieve\&db=PubMed\&list_ uids $=27503870 \&$ dopt $=$ Abstract).

41. Pauly B, MacDonald M, O'Brian W, Hancock T, Perkin K, Martin W, Riishede J. Health Equity Tools. Victoria, BC: Equity Lens in Public Health, 2013. Available from: http:// nccdh.ca/resources/entry/health-equity-tools (accessed May 15, 2017).

42. Welch VA, Petticrew M, O’Neill J, Waters E, Armstrong $R$, Bhutta ZA, Francis D, Koehlmoos TP, Kristjansson E, Pantoja T, Tugwell P. Health equity: evidence synthesis and knowledge translation methods. Syst Rev [Internet]. 2013;2:43. DOI: http://dx.doi.org/10.1186/2046-4053-2-43. PubMed (https://www.ncbi.nlm.nih.gov/ pubmed/28379440?dopt=Abstract).

43. World Health Organization. Ottawa Charter for Health Promotion. Geneva; 1986. Available from: http://www. who.int/healthpromotion/conferences/previous/ottawa/en/ (accessed May 15, 2017).

44. de Leeuw E. Engagement of sectors other than health in integrated health governance, policy, and action. Annu Rev Public Health. 2017;38:329-49. DOI: http://dx.doi.org/10.1146/annurev-publhealt h-031816-044309. PubMed (https://www.ncbi.nlm.nih.gov/ pubmed/28125390?dopt=Abstract).

45. Dean HD, Williams KM, Fenton KA. From theory to action: applying social determinants of health to public health practice. Public Health Reports. 2013;128(Suppl 3):1-4. DOI: http://dx.doi.org/10.1177/00333549131286S301. PubMed (https://www.ncbi.nlm.nih.gov/pmc/articles/PMC3945442/).

46. Kass NE. An ethics framework for public health. Am J Public Health [Internet]. 2001;91(11):1776-82. DOI: http://dx.doi. org/10.2105/AJPH.91.11.1776. PubMed (https://www.ncbi. nlm.nih.gov/pubmed/11684600?dopt=Abstract).

47. Gruskin S, Daniels N. Process is the point. Justice and human rights: priority setting and fair deliberative process. Am J Public Health [Internet]. 2008; 98(9): 1573-7. DOI: http:// dx.doi.org/10.2105/AJPH.2007.123182. PubMed (https:// www.ncbi.nlm.nih.gov/entrez/query.fcgi?cmd=Retrieve \&db= PubMed\&list_uids=18633088\&dopt=Abstract).

48. Sabo S, Ingram M, Reinschmidt KM, Schachter K, Jacobs L, Guernsey de Zapien J, Robinson L, Carvajal S. Predictors and a framework for fostering community advocacy as a community health worker core function to eliminate health disparities. Am J Public Health [Internet]. 2013;103(7):e67-73. DOI: http://dx.doi.org/10.2105/AJPH.2012.301108. PubMed 
(https://www.ncbi.nlm.nih.gov/entrez/query.fcgi?cmd=Retrie ve\&db=PubMed\&list_uids=23678904\&dopt=Abstract).

49. Andermann A. Evidence for Health: From Patient Choice to Global Policy. Cambridge: Cambridge University Press, 2013. Available from: http://www.cambridge.org/gb/knowledge/ isbn/item6945171/ (accessed May 15, 2017).

50. National Collaborating Centre for Aboriginal Health. Aboriginal health: a patchwork of policies and legislation. Victoria; 2011. Available from: http://www.nccah-ccnsa. ca/252/Aboriginal_health__A_patchwork_of_policies_and_ legislation.nccah\#1 (accessed May 15, 2017).

51. Lavoie JG. Policy silences: why Canada needs a national First Nations, Inuit and Métis health policy. Int J Circumpolar Health. 2013;72(1):22690-8. DOI: http://dx.doi.org/10.3402/ ijch.v72i0.22690. PubMed (https://www.ncbi.nlm.nih. gov/entrez/query.fcgi?cmd=Retrieve\&db=PubMed\&lis t_uids=24380077\&dopt=Abstract).

52. Kolahdooz F, Nader F, Yi K, Sharma S. Understanding the social determinants of health among Indigenous Canadians: priorities for health promotion policies and actions. Glob Health Action [Internet]. 2015;8(1):27968. DOI: http://dx.doi. org/10.3402/gha.v8.27968. PubMed (https://www.ncbi.nlm. nih.gov/entrez/query.fcgi?cmd=Retrieve \&db=PubMed\&li st_uids=28156855\&dopt=Abstract).

53. Pardy B. Seven deadly sins of Canadian water law. J Env Law \& Prac. 2004;13:89-110.

54. O'Connor DR. Report of the Walkerton Inquiry: The Events of May 2000 and Related Issues. Toronto: Queen's Printer for Ontario, 2002. Available from: http://www.archives.gov. on.ca/en/e_records/walkerton/report1/ (accessed May 15, 2017).

55. Canadian Council of Ministers for the Environment. Federal-Provincial-Territorial Committee on Drinking Water and the CCME Water Quality Task Group. From Source to Tap: Guidance on the Multi-Barrier Approach to Safe Drinking Water. Ottawa; 2004. Available from: http://www. ccme.ca/files/Resources/water/source_tap/mba_guidance_ doc_e.pdf (accessed May 15, 2017).

56. Rideout K, Oickle D. Equity in Environmental Health Practice: Findings of a Pilot Study. Vancouver, BC: The National Collaborating Centre for Environmental Health (NCCEH) and the National Collaborating Centre for Determinants of Health (NCCDH), 2015. Available from: http://www.ncceh.ca/sites/ default/files/Equity_EH_practice_April_2015.pdf (accessed May 15, 2017).

57. Lavoie JG, Boulton FA, Gervais L. Regionalization as an opportunity for meaningful Indigenous participation in healthcare: Comparing Canada and New Zealand. The International Indigenous Policy Journal [Internet]. 2012;3(1). Available from: http://ir.lib.uwo.ca/iipj/vol3/iss1/2/ (accessed May 15, 2017). DOI: http://dx.doi.org/10.18584/ iipj.2012.3.1.2.

58. Barry J. Rethinking Green Politics: Nature, Virtue and Progress. London: SAGE Publishing, 1999.

59. Griffin PM, Karmali MA. Emerging public health challenges of shiga toxin-producing Escherichia coli related to changes in the pathogen, the population, and the environment. Clin Infect Dis. 2017;64(3):371-6. DOI: http://dx.doi. org/10.1093/cid/ciw708. PubMed (https://www.ncbi.nlm. nih.gov/entrez/query.fcgi?cmd=Retrieve\&db=PubMed\&li st_uids=27986670\&dopt=Abstract).

60. Ruscio BA, Brubaker M, Glasser J, Hueston W, Hennessy T. One Health - a strategy for resilience in a changing arctic. Int J Circumpolar Health. 2015;74(1):27913. DOI: http://dx.doi. org/10.3402/ijch.v74.27913. PubMed (https://www.ncbi.nlm. nih.gov/entrez/query.fcgi?cmd=Retrieve\&db=PubMed\&li st_uids=28417805\&dopt=Abstract).

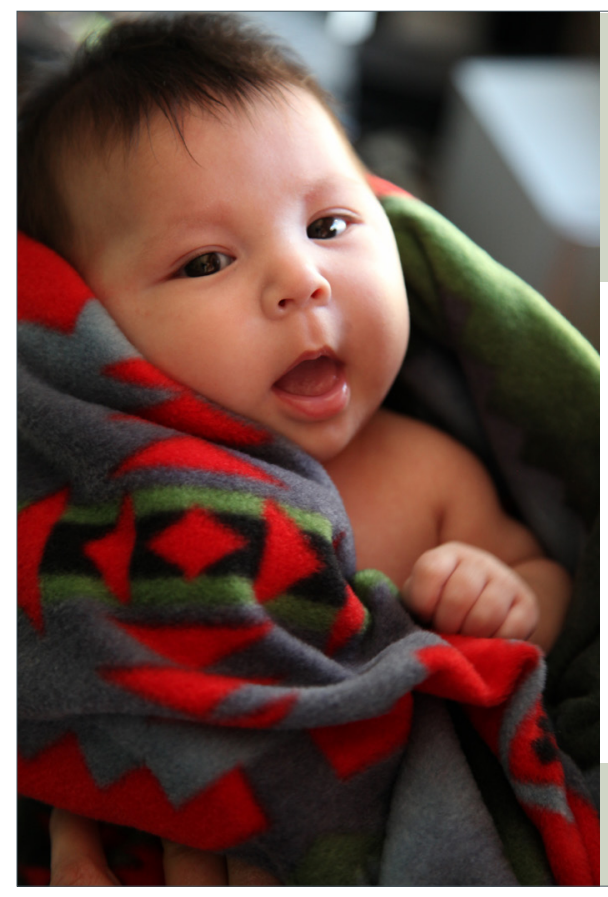

\section{Research is underway to develop a new vaccine for a pathogen emerging in our communities}

\section{Read about it in CCDR's May 2017 issue: Implementation Science}

$[0$

Developing a vaccine for Haemophilus influenzae serotype a: Proceedings of a workshop

Cox AD, Barreto L, Ulanova M, Bruce MG, Tsang RSW on behalf of the Conference contributors. Developing a vaccine for Haemophilus influenzae serotype a: Proceedings of a workshop. Can Commun Dis Rep. 2017;43(5):89-95.

Get the full issue: Web search "CCDR+Implementation Science" 